\title{
INFLUENCE OF TIME ON PHTHALATE ESTERS CONCENTRATIONS IN VEHICLE PLASTIC MATERIALS DURING VEHICLE OPERATION
}

\author{
Michal Kucera ${ }^{1}$, Marcela Jandlova ${ }^{2}$, Alzbeta Jarosova ${ }^{2}$, Stefan Cornak ${ }^{1}$ \\ ${ }^{1}$ University of Defence in Brno, Czech Republic; ${ }^{2}$ Mendel University in Brno, Czech Republic \\ michal.kucera@unob.cz,marcela.jandlova@mendelu.cz, alzbeta.jarosova@mendelu.cz, \\ stefan.cornak@unob.cz
}

\begin{abstract}
The aim of this work was to determine the concentrations of phthalic acid esters (PAEs) in plastic materials used in automobiles and monitor the changes in concentrations over time. The phthalates can be released into the car interior during the operation of the vehicle and thereby inhaled by the driver, or the PAEs can migrate from plastics to the surrounding contact materials. Esters of phthalic acid are used as plasticizer of plastics. They are not chemically bonded in polymers, so they can migrate into materials, which are in contact with them, leach or evaporate into the environment. Phthalic acid esters have teratogenic and carcinogenic effects and negative effects on the male reproductive system. In this study the most commonly used phthalates were determined: dibutyl phthalate (DBP) and di-(2-ethylhexyl) phthalate (DEHP). Nine samples of plastic materials that are used in the car interior were analysed. The samples were new plastics, which were made for car mounting. Each sample of the plastic material was subdivided into individual components, from which the sample consists, and each part of every sample was analysed separately. The first sample analysis was performed immediately after the obtaining of the plastic samples (after the plastics production) and subsequently after 3 months. The samples of plastic automobile components were transported in the car in the period between the two analyses. The car was used in normal operation. It simulated the actual plastic environment, where these plastics are normally placed. All analyses were performed in triplicate. In total, they were 18 samples of plastics analysed and 108 analyses were performed. Phthalic acid esters were determined by high pressure liquid chromatography.
\end{abstract}

Keywords: microclimate of vehicles, variables, modelling, phthalates, plastic material.

\section{Introduction}

With the growth of road vehicles, the number of road accidents increases. Long-term analysis of traffic accidents shows that most road accidents (more than $90 \%$ ) are caused by motor vehicle drivers. Significant influence on the driver's activity has also the environment in the vehicle and in addition the proper diet (nutrition, exercise, sleep, etc.). The interior of the vehicle (Fig. 1) may be contaminated by harmful substances entering the vehicle from the outside (e.g., exhalation resulting from the combustion of fossil fuels), but also by the harmful substances generated inside the vehicle during the operation of the crew (e.g., breathing and insufficient ventilation) and from the exhalations that may result from the release from the interior material (e.g., phthalates, formaldehyde, etc.).

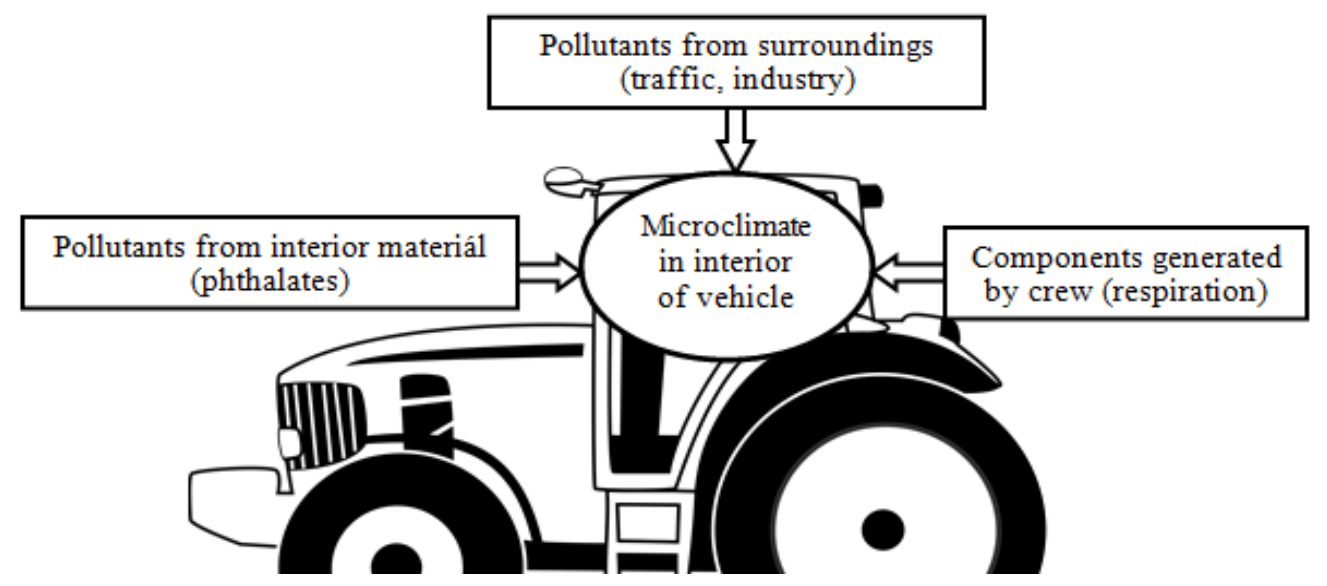

Fig. 1. Schematic of external and internal contaminations of cabin air

The article builds on the existing research in 2017 at the University of Defense in Brno at thirty randomly selected buses at the Brno Public Transportation Company that in a normal operation in monitored vehicles, where there were about 40 people, the measured carbon monoxide concentrations ranged from 900 to $1200 \mathrm{ppm}$ [8]. Already with this increased concentration of $\mathrm{CO}_{2}$, the driver may increase his sleepiness, lethargy, fatigue, etc. The decrease in the concentration of the driver may be 
the cause of a traffic accident. The aim of the authors is to discuss the internal effects of the microclimate, perform individual pollutant evaluations. The level of microclimate inside the vehicle can greatly influence the harmful substances released from the interior material (phthalates, formaldehyde, etc.) Phthalic acid esters are ubiquitous environmental contaminants. Chronic intoxication, in particular DEHP, has carcinogenic and teratogenic effects and negatively affects the reproductive capacity of the organism. Acute toxicity of phthalates (LD50 units to tens of $\mathrm{g}^{\mathrm{kg}} \mathrm{g}^{-1}$ body weight) is manifested by malaise, hallucinations, dizziness, somnolence, vision disorder, decreased blood pressure [7]. DEHP is used in the manufacture of plastics, which improves their flexibility, forms up to $40 \%$ of vinyl plastic materials, it is also found in toys, hoses, garments, packing materials, etc. [1; 5]. DBP is also a plasticizer, it is found in polyvinyl chloride plastics, in paints, adhesives, cosmetics, etc. [6].The most significant phthalate intake is diet, for low molecular weight phthalates by inhalation, for higher molecular weight phthalates by dust, another possibility of phthalate intake is the skin, dust, air and personal care products [2].As for the concentrations of the above-mentioned phthalates in the air, the indoor concentrations are higher than in outdoors, for DBP average values for Europe outside $15.8 \mathrm{ng} \cdot \mathrm{m}^{-3}$, internal $1032 \mathrm{ng} \cdot \mathrm{m}^{-3}$, for DEHP Europe, outdoor $21.9 \mathrm{ng} \cdot \mathrm{m}^{-3}$ indoor $245 \mathrm{ng} \cdot \mathrm{m}^{-3}[3]$.

\section{Materials and methods}

This is a research on how and whether the concentration of phthalic acid esters in plastics changes. The choice of the concentration of phthalates in plastics has been determined from the previous experience of the authors and research at the University of Defense in Brno, where the 3 month measurement interval reflects the changes in plastics. Methodological disagreements and continuous measurement results are presented in this paper.

The analysis of automotive plastic was carried out. Each plastic was divided into individual layers from, which it was composted of (Table 1), and each layer was analyzed separately. The plastic sample for the analysis was weighed $0.5 \mathrm{~g}$. The analyzes were performed in triplicate.

Each part of the plastic was mechanically comminuted, placed in a mixture of solvent dichloromethane: hexane (1: 1) for 72 hours, shaken for 1 hour and then 2 times 0.5 hours and filtered. The filtrate was evaporated on a vacuum evaporator and dried with nitrogen. The evaporator was transferred to a $10 \mathrm{~mL}$ vial by hexan. If the dissolved residue was clear, it was quantitatively transferred to a $1.5 \mathrm{ml}$ vial, dried with nitrogen and supplemented with $1 \mathrm{ml}$ of acetonitrile. The slightly cloudy residue was centrifuged, the hexane layer was transferred to a $1.5 \mathrm{ml}$ vial, dried with nitrogen and supplemented with $1 \mathrm{ml}$ of acetonitrile. If the dissolved residue was colored or cloudy, it was first purged with sulfuric acid and transferred to a $1.5 \mathrm{ml}$ vial, dried with nitrogen and supplemented with $1 \mathrm{ml}$ of acetonitrile. Purification by sulfuric acid: $1 \mathrm{ml}$ of $96 \% \mathrm{H}_{2} \mathrm{SO}_{4}$ was added to the hexane solution with a vial sample, $10 \mathrm{~min}$. centrifuged on centrifuge $(10 \mathrm{~min}, 3000 \mathrm{rpm}$, $-4{ }^{\circ} \mathrm{C}$ ), the upper layer was removed into the waste, $2 \mathrm{ml}$ of $65 \% \mathrm{H}_{2} \mathrm{SO}_{4}$ and $1 \mathrm{ml}$ of hexane were added, 10 min. shaken, centrifuged $\left(10 \mathrm{~min} ., 3000 \mathrm{rpm},-4^{\circ} \mathrm{C}\right)$, topped up in a male vial, and $1 \mathrm{ml}$ of hexane added for $10 \mathrm{~min}$. shaken, spin centrifuged $\left(10 \mathrm{~min}, 3000 \mathrm{rpm},-4^{\circ} \mathrm{C}\right)$, removed the top layer in the male vial, add $1 \mathrm{ml}$ of hexane for $10 \mathrm{~min}$. shaken, centrifuged $\left(10 \mathrm{~min}, 3000 \mathrm{rpm},-4^{\circ} \mathrm{C}\right)$, the top layer removed into a male vial. The contents of the male vial are dried and supplemented with $1 \mathrm{ml}$ of acetonitrile. The prepared samples were analyzed by HPLC (high-performance liquid chromatography), with UV detection on a Zorbax Eclipse C8 column, at a wavelength of $224 \mathrm{~nm}$, mobile phase acetonitrile. Evaluation was performed by Agilent Chemstation software for LC and LC/MS systems. Samples were analyzed about one month after production (0 month)and after three months simulation of the operating mode, when the plastics for analysis were carried in the winter months. in the automobile, spread out on a non-contaminating pad.

Analyzes were carried out at the Mendel University in Brno at the Institute of Food Technology according to the method of Gajdůšková et.al (1996). 18 samples of plastic were analyzed and 108 analyzes were performed.

The results were processed by Microsoft Excel 2010 and by Statistica 12. Firstly, the Grubbs' test was used for to determine the outlier data, then the normality test Shapiro-Wilk test. Finally, the t-test was used for comparison of the mean values $(\alpha=0.05)$. Concentration of dibutyl phthalate in 0 month 
with concentration of dibutyl phthalate in 3 months and concentration of di-(2-ethylhexyl) phthalate in 0 month with concentration of di-(2-ethylhexyl) phthalate in 3 months were compared.

Table 1

Analyzed samples

\begin{tabular}{|c|c|c|c|}
\hline Nr. & \multicolumn{3}{|c|}{ Specification of samples } \\
\hline 1 & \multirow{2}{*}{$\begin{array}{l}\text { asymmetric } \\
\text { square }\end{array}$} & stiffer foam gray intermediate layer & blown foam \\
\hline 2 & & rigid black plastic (medium is gray) & PP or PA \\
\hline 3 & \multirow{3}{*}{ bubble } & soft black plastic & rubber surface \\
\hline 4 & & stiffer foam gray intermediate layer & blown foam \\
\hline 5 & & rigid black plastic (medium is gray) & $\mathrm{PP}$ or PA \\
\hline 6 & \multirow[t]{2}{*}{ dashboard } & stiffer foam gray intermediate layer & blown foam \\
\hline 7 & & rigid black plastic (medium is gray) & PP or PA \\
\hline 8 & \multirow{3}{*}{ longitudinal } & soft black plastic & rubber surface \\
\hline 9 & & stiffer foam gray intermediate layer & blown foam \\
\hline 10 & & rigid black plastic (medium is gray) & PP or PA \\
\hline 11 & \multirow[b]{2}{*}{$\begin{array}{l}\text { ventilation } \\
\text { grids }\end{array}$} & solid black plastic rectangular shape & hard plastic PP TX40 \\
\hline 12 & & $\begin{array}{l}\text { soft edge, rigid black plastic of } \\
\text { rectangular shape }\end{array}$ & soft plastic TPV -(EPDM+PP) \\
\hline 13 & pad & soft black plastic & soft plastic TPV -(EPDM+PP) \\
\hline 14 & \multirow{2}{*}{ flapper } & rigid black plastic & hard plastic PP TX20 \\
\hline 15 & & soft edge & soft plastic TPV -(EPDM+PP) \\
\hline 16 & $\begin{array}{l}\text { airflow } \\
\text { regulator }\end{array}$ & $\begin{array}{l}\text { hard black plate with a solid metal } \\
\text { edge on one side }\end{array}$ & \\
\hline 17 & \multirow[b]{2}{*}{$\begin{array}{l}\text { from the } \\
\text { steering } \\
\text { wheel }\end{array}$} & skin and glue & skin with glue \\
\hline 18 & & $\begin{array}{l}\text { harder black plastic that was around } \\
\text { the center of the steering wheel }\end{array}$ & $\begin{array}{l}\text { softer plastic that was around the } \\
\text { center of the steering wheel, this } \\
\text { part is in direct contact with the } \\
\text { driver }\end{array}$ \\
\hline
\end{tabular}

\section{Results and discussions}

Average concentrations of phthalic acid esters, during a three-month exposure period, during stimulations, in automotive interior, decline by 9 from 18 samples for DBP and by 16 from 18 samples for DEHP. Average concentrations of dibutyl phthalate and di-2-ethylhexyl phthalate in car interior plastics after three months of operating mode are given in Table 2.

Average concentrations for DBP in car plastics ranged from 1.31 to $326.10 \mu \mathrm{g} \cdot \mathrm{g}^{-1}$ of plastic in the zero month. In the third month average concentrations for DPB in car plastics ranged from 1.73 to $161.54 \mu \mathrm{g} \cdot \mathrm{g}^{-1}$ plastic. Average concentrations for DEHP in the zero month ranged from 1.69 to $185.70 \mu \mathrm{g} \cdot \mathrm{g}^{-1}$ plastic and in the 3rd month from 3.74 to $45.45 \mu \mathrm{g} \cdot \mathrm{g}^{-1}$ plastic. It is reported that higher molecular weight phthalates are less volatile than lower molecular weight phthalates (Velíšek, Hajšlová, 2009), but in our experiment higher phthalate was more volatile than lower phthalate. Therefore, it can be concluded that the decrease in phthalates in plastic samples resulted in an increase in the concentration of phthalic acid esters in the car environment. Increasing concentrations of phthalates in the plastic samples during the simulation of the parts of the car plastics exposure could be caused by mutual contact of plastic samples with each other and probably there was migration of phthalates between the samples.

After the t-test for comparison of mean values $(\alpha=0.05)$, a statistically significant difference in the samples for DBP at 7 and 16 was determined, for DEHP for 2, 4, 5, 8, 9, 11, $16(p<0.05)$.

In the study [9], investigating the release of DEHP from PVC flooring, depending on the temperature, when temperatures ranged from $23^{\circ} \mathrm{C}$ to $61{ }^{\circ} \mathrm{C}$, it was found that with increasing temperature DEHP released more into the environment, but also decreased adsorption on the wall of the chamber, in which the experiment was in progress. 
Average concentrations of dibutyl phthalate and di-2-ethylhexyl phthalate in car interior

Table 2 plastics after three months of operating mode

\begin{tabular}{|c|c|c|c|c|c|c|c|c|c|}
\hline \multirow{3}{*}{ 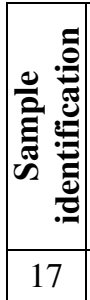 } & \multirow{3}{*}{ 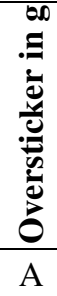 } & \multirow{2}{*}{ 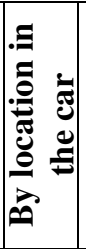 } & \multirow{2}{*}{\multicolumn{3}{|c|}{ Specifications sample }} & \begin{tabular}{|c|} 
Month 0 \\
diameter \\
of DBP \\
\end{tabular} & \begin{tabular}{|c|} 
Month 3 \\
diameter \\
of DBP \\
\end{tabular} & \begin{tabular}{|c|} 
Month 0 \\
average \\
DEHP \\
\end{tabular} & $\begin{array}{l}\text { Month } 3 \\
\text { DEHP } \\
\text { average } \\
\end{array}$ \\
\hline & & & & & & \multicolumn{4}{|c|}{$\mu \mathrm{g} \cdot \mathrm{g}^{-1}$ plastic } \\
\hline & & \multirow{13}{*}{ 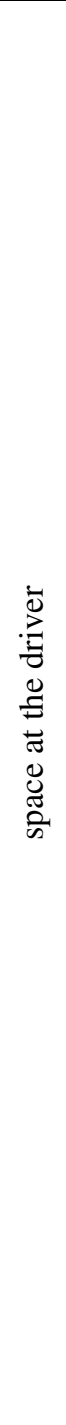 } & & skin and glue & skin with glue & 19.58 & 7.15 & 52.49 & 34.75 \\
\hline 18 & $\mathrm{~B}$ & & $\begin{array}{l}\text { from the } \\
\text { steering } \\
\text { wheel }\end{array}$ & $\begin{array}{c}\text { harder black } \\
\text { plastic that was } \\
\text { around the center } \\
\text { of the steering } \\
\text { wheel }\end{array}$ & $\begin{array}{l}\text { softer plastic that } \\
\text { was around the } \\
\text { center of the } \\
\text { steering wheel, } \\
\text { this part is in } \\
\text { direct contact with } \\
\text { the driver }\end{array}$ & 4.63 & 3.84 & 8.83 & 6.00 \\
\hline 1 & $\mathrm{C}$ & & $\begin{array}{c}\text { asymmetrical } \\
\text { square from }\end{array}$ & $\begin{array}{c}\text { stiffer foam gray } \\
\text { intermediate layer }\end{array}$ & blown foam & 151.84 & 151.87 & 91.28 & 26.20 \\
\hline 2 & $\mathrm{D}$ & & $\begin{array}{c}\text { the } \\
\text { dashboard }\end{array}$ & $\begin{array}{l}\text { solid black plastic } \\
\text { (medium is gray ) }\end{array}$ & $\mathrm{PP}$ or PA & 9.11 & 14.95 & 45.49 & 3.74 \\
\hline 3 & $\mathrm{E}$ & & \multirow{3}{*}{$\begin{array}{c}\text { Bubble from } \\
\text { the } \\
\text { dashboard }\end{array}$} & soft black plastic & rubber surface & 326.10 & 54.45 & 145.15 & 40.40 \\
\hline 4 & $\mathrm{~F}$ & & & $\begin{array}{c}\text { stiffer foam gray } \\
\text { intermediate layer }\end{array}$ & blown foam & 81.88 & 53.56 & 23.00 & 12.23 \\
\hline 5 & $\mathrm{G}$ & & & $\begin{array}{l}\text { solid black plastic } \\
\text { (medium is gray)) }\end{array}$ & $\mathrm{PP}$ or PA & 15.60 & 40.37 & 54.47 & 5.01 \\
\hline 13 & $\mathrm{H}$ & & $\begin{array}{l}\text { pad for } \\
\text { storing } \\
\text { things }\end{array}$ & soft black plastic & $\begin{array}{c}\text { soft plastic TPV - } \\
(\text { EPDM+PP)) }\end{array}$ & 9.71 & 8.06 & 65.22 & 40.41 \\
\hline 11 & I & & \multirow{2}{*}{$\begin{array}{l}\text { ventilation } \\
\text { grids }\end{array}$} & $\begin{array}{l}\text { solid black plastic } \\
\text { rectangular shape }\end{array}$ & $\begin{array}{c}\text { hard plastic PP } \\
\text { TX40 }\end{array}$ & 32.52 & 1.73 & 33.02 & 3.93 \\
\hline 12 & $\mathrm{~J}$ & & & $\begin{array}{l}\text { soft edge, rigid } \\
\text { black plastic } \\
\text { rectangular shape }\end{array}$ & $\begin{array}{l}\text { soft plastic TPV - } \\
\quad(\mathrm{EPDM}+\mathrm{PP})\end{array}$ & 2.48 & 66.98 & 2.62 & 17.06 \\
\hline 14 & $\mathrm{~K}$ & & \multirow{2}{*}{$\begin{array}{c}\text { flap from the } \\
\text { airflow } \\
\text { controller }\end{array}$} & rigid black plastic & $\begin{array}{c}\text { hard plastic PP } \\
\text { TX40 }\end{array}$ & 1.31 & 6.46 & 1.69 & 18.38 \\
\hline 15 & $\mathrm{~L}$ & & & soft edge & $\begin{array}{c}\text { soft plastic TPV- } \\
(\text { EPDM+PP) }\end{array}$ & 51.11 & 29.17 & 140.77 & 22.21 \\
\hline 16 & M & & $\begin{array}{l}\text { airflow } \\
\text { regulator }\end{array}$ & $\begin{array}{l}\text { a hard black plat } \\
\text { with a solid metal } \\
\text { rantal on one side }\end{array}$ & - & 167.82 & 27.07 & 104.50 & 11.80 \\
\hline 6 & $\mathrm{~N}$ & \multirow{5}{*}{ 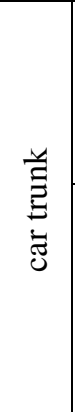 } & \multirow{2}{*}{$\begin{array}{c}\text { Tile from the } \\
\text { car trunk }\end{array}$} & $\begin{array}{l}\text { stiffer foam gray } \\
\text { intermediate layer }\end{array}$ & blown foam & 146.03 & 47.08 & 185.70 & 45.40 \\
\hline 7 & $\mathrm{O}$ & & & $\begin{array}{c}\text { rigid black plastic } \\
\text { (medium is gray) }\end{array}$ & PP or PA & 10.99 & 28.49 & 129.69 & 6.59 \\
\hline 8 & $\mathrm{P}$ & & \multirow{3}{*}{$\begin{array}{l}\text { longitudinal } \\
\text { plastic from } \\
\text { the car trunk }\end{array}$} & soft black plastic & rubber surface & 197.12 & 161.54 & 158.07 & 24.94 \\
\hline 9 & $\mathrm{Q}$ & & & $\begin{array}{l}\text { stiffer foam gray } \\
\text { intermediate layer }\end{array}$ & blown foam & 43.13 & 106.87 & 162.45 & 12.68 \\
\hline 10 & $\mathrm{R}$ & & & $\begin{array}{l}\text { rigid black plastic } \\
\text { (medium is gray) }\end{array}$ & $\mathrm{PP}$ or PA & 36.17 & 40.19 & 7.75 & 5.61 \\
\hline
\end{tabular}

In the study [10], investigating released phthalate concentrations indoors in newly decorated rooms, they found that the highest concentrations were in the living room $\left(17364 \mathrm{ng} \cdot \mathrm{m}^{-3}\right)$, less in the 
study $\left(11390 \mathrm{ng} \cdot \mathrm{m}^{-3}\right)$, and the least in the bedroom $\left(9739 \mathrm{ng} \cdot \mathrm{m}^{-3}\right)$. The living room was most decorated with plastic objects. The value exceeded the carcinogenic risk limit set by the U.S. EPA.

\section{Conclusions}

The results of the experimental research have shown that concentrations of DEHP dropped in more samples than DBP concentrations during the exposure of plastics in automotive environments. Of the 18 analyzed plastic samples the average concentration of DEHP decreased in 16 samples and of DBP in 9 samples. Average concentrations of DEHP in 0 month ranged from 1.69 to $185.70 \mu \mathrm{g} \cdot \mathrm{g}^{-1}$ of plastic, and in the 3rd month from 3.74 to $45.40 \mu \mathrm{g} \cdot \mathrm{g}^{-1}$ of plastics. Average concentrations of DBP in month 0 ranged from 1.31 to $326.10 \mu \mathrm{g} \cdot \mathrm{g}^{-1}$ of plastic and in the 3rd month from 1.73 to $161.54 \mu \mathrm{g} \cdot \mathrm{g}^{-1}$ of plastic. In the event of optimization a suitable microclimate of the vehicle, elimination of the driver fatigue is ensured, which leads to the elimination of the risk of a traffic accident. That is why the authors recommend more to address the issue in research institutes and medical institutions, including establishing closer synergy with the vehicle manufacturers.

\section{Acknowledgement}

The presented paper has been prepared with the support of the Ministry of Defence of the Czech Republic, Partial Project for Institutional Development, K-202, Department of Combat and Special Vehicles, University of Defence, Brno.

\section{References}

[1] Kalpakjian S., Schmid S.R. Manufacturing engineering and technology. Sixth edition. New York: Prentice Hall, 2010, 1176 p.

[2] Bui T. T. Assessing human exposure to phthalates, alternative plasticizers and organophosphate esters.Stockholm: US-AB., 2017, 59 p. ISBN 978-91-7649-699-2

[3] Clark K., Cousins I.T., Mackay D., Yamada K. Observed Concentrations in the Environment. In: Staples C. A. (ed): Phthalate esters. Berlin: Springer-Verlag, 2003, pp. 125-177.

[4] Gajdůšková V., Jarošová A., Ulrich R. Occurrence of phthalic acid esters in food packaging materials. Veterinary Research Institute, Brno. PotravinářskéVědy, 14,1996, pp. 99-108.

[5] Miles-Richardson S., Bosch S., Swarts S. Llados F., Gray D. A. Toxicological profile fordi (2-ethylhexyl) phthalate. In: Toxic Substances Portal [online]. ATSDR Agency for Toxic Substances and Disease Registry, 2002.

[6] Taylor J., Ingerman L., Gray D. A., Little S. Amata R. Toxicological profile for di-n-butyl phthalate. In: Toxic Substances Portal [online]. ATSDR Agency for Toxic Substances and Disease Registry, 2001.

[7] Velíšek J., Hajšlová J. Chemiepotravin II. 3. vyd., Tábor: OSSIS, 2009, 644 p. ISBN: 978-8086659-16-9

[8] Kučera M., Čorňák Š., Svatošová V. Specific aspects of microclimate in vehicles. In: International Conference on Military Technologies (ICMT). Brno: University of Defence, 2017, 175-178 p.

[9] Per Axel C., Liu1 Z., Kofoed-Sørensen V., Little J., Wolkoff. Influence ofTemperature on the Emissionof Di-(2-ethylhexyl) phthalate (DEHP) from PVC Flooring in theEmission Cell FLEC. Environmental Science \& Technology [online]. 2011, 46 p. ISSN 0013-936X.

[10] Pei X.Q., Song M., Guo M., Mo F.F. Shen X.Y. Concentration and risk assessment of phthalates present in indoor air from newly decorated apartments. Atmospheric Environment [online]. 2013, 68 p. ISSN 13522310 